\title{
PENGARUH VARIASI ZAT PENGATUR TUMBUH IAA, BAP, KINETIN TERHADAP METABOLIT SEKUNDER KALUS SIRIH HITAM (Piper betle L. Var Nigra)
}

\author{
Junairiah Junairiah $^{1 *}$, Nurul Sofi Amalia ${ }^{1}$, Y. Sri Wulan Manuhara ${ }^{1}$, Ni’matuzzahroh $^{\prime}$ \\ Ni'matuzahroh ${ }^{1}$, Lilis Sulistyorini ${ }^{2}$ \\ ${ }^{1}$ Departemen Biologi, Fakultas Sains dan Teknologi, Universitas Airlangga \\ ${ }^{2}$ Fakultas Kesehatan Masyarakat, Universitas Airlangga \\ *email : alip.jun1@gmail.com
}

Received 1 October 2019

Accepted 31 December 2019

\begin{abstract}
Abstrak
Piper betle L. var Nigra (sirih hitam) merupakan salah satu jenis tanaman obat yang berpotensi untuk dikembangkan dengan metode kultur jaringan. Penelitian ini bertujuan untuk mengetahui pengaruh variasi zat pengatur tumbuh Indole Acetic Acid (IAA), Benzyl Amino Purine (BAP), Kinetin terhadap senyawa metabolit sekunder yang terdapat kalus sirih hitam. Eksplan daun dari sirih hitam ditanam pada medium Murashige dan Skoog dengan 4 perlakuan kombinasi (I1,0K1,0; I1,0K1,5; I1B1,5; I0,5B0,5). Kalus dipelihara selama 8 minggu. Simplisia kalus sirih hitam di maserasi menggunakan pelarut metanol dan diidentifikasi menggunakan Gas Chromatography Mass Spectra (GCMS). Berdasarkan analisis GCMS menunjukkan bahwa senyawa metabolit sekunder dengan presentase tertinggi terdapat pada masing- masing perlakuan yaitu senyawa gamma sitosterol $(14,88 \%)$ pada perlakuan I1,0K1,0 ; senyawa 14 -Beta H Pregna $(15,94 \%)$ pada perlakuan $\mathrm{I} 1,0 \mathrm{~K} 1,5$ serta senyawa beta-d-glucopyranoside $(15,54 \%)$ pada perlakuan $\mathrm{I} 0,5 \mathrm{~B} 0,5$; dan senyawa beta$d$-glucopyranoside $(5,63 \%)$ pada perlakuan $\mathrm{I} 1,0 \mathrm{~B} 1,5$.
\end{abstract}

Katakunci: Kalus, Piper betle L. var Nigra, senyawa metabolit sekunder

\begin{abstract}
Piper betle L. Var Nigra (black betel) is one type of medicinal plant that has the potential to be developed by tissue culture method. This study was aims to determine the effect of variations in growth regulator Indole Acetic Acid (IAA), Benzyl Amino Purine (BAP), and Kinetin on secondary metabolite compounds contained in black betel callus. The explant of black betel's leaf was cultured on Murashige and Skoog medium with four combination treatments (I1.0K1.0; I1.0K1.5; I1B1.5; I0.5B0.5). The callus was maintained for eight weeks. Simplisia of black betel's callus was macerated using methanol solvent and identified using Gas Chromatography Mass Spectra (GCMS). GCMS analysis showed that secondary metabolites with the highest percentage in each treatment were gamma sitosterol compound $(14.88 \%)$ in treatment I1.0K1.0; 14-Beta H Pregna compound $(15.94 \%)$ in I1.0K1.5 treatment and beta-d-glucopyranoside compound (15.54\%) in I0.5B0.5 treatment; and beta-d-glucopyranoside compound (5.63\%) in I1.0 B1.5 treatment.
\end{abstract}

Keywords: Callus, Piper betle L. Var Nigra, secondary metabolite compounds 


\section{Pendahuluan}

Salah satu jenis tanaman yang memiliki khasiat sebagai obat adalah tanaman sirih hitam (Piper betle L. var Nigra). Sirih hitam termasuk ke dalam famili Piperaceae yang berpotensi sebagai antioksidan, antikanker, antidiabetik, dan antiinflamasi yang dapat menyembuhkan berbagai penyakit. Menurut Hutapea (2000), tanaman sirih mengandung metabolit sekunder berupa saponin, flavonoid, polifenol, dan minyak atsiri triterpenoid, minyak atsiri (yang terdiri atas khavikol, chavibetol, karvakrol, eugenol, monoterpena, estragol), seskuiterpen, gula dan pati.

Secara umum daun sirih mengandung minyak atsiri sampai 4,2\% (Kartasapoetra 1992), senyawa fenil propanoid, dan tanin (Mahendra 2005). Senyawa ini bersifat antimikroba dan antijamur yang dapat menghambat beberapa jenis bakteri antara lain Staphylococcus aureus, Escherichia coli, Salmonella sp, Pasteurella sp, Klebsiella $s p$, dan dapat menghambat pertumbuhan Candida Albicans (Agusta 2000, Hariana 2007). Menurut Rija'i (2015) sirih hitam (Piper betle L.) mengandung metabolit sekunder berupa alkaloid, flavonoid, saponin, tannin, steroid, triterpenoid, dan polifenolat.

Banyaknya manfaat dari sirih hitam karena kandungan bioaktif di dalamnya maka perlu dilakukan suatu penelitian yang mengarah kepada pencarian metode yang efektif dan efisien untuk penyediaan bahan bahan aktif bermanfaat dari sirih hitam dalam jumlah lebih banyak dengan waktu yang lebih singkat, yaitu dengan kultur jaringan. Salah satu metode kultur jaringan adalah kultur kalus, hal ini karena kalus memiliki multiplikasi tinggi, dengan kata lain dimana sel sel kalus dapat dipisahkan dan diinduksi untuk berdiferensiasi menjadi embrio somatik sehingga mudah diperbanyak dan menghasilkan sifat yang sama sesuai dengan induknya. Selain itu juga dapat digunakan sebagai bahan awal dilakukannya kultur protoplas dan suspensi sel. Kultur kalus sering digunakan untuk memperoleh tanaman bebas virus, embriogenesis somatik, regenerasi varian genetika, dan menghasilkan senyawa metabolit sekunder (Zulkarnain, 2009).

Auksin merupakan zat pengatur tumbuh yang berfungsi untuk perpanjangan sel dan pembesaran jaringan, pembelahan sel, pembentukan akar adventif dan menghambat pembentukan tunas aksiler dan adventif (Sutriana et al, 2012). Auksin pada konsentrasi rendah menyebabkan pembentukan akar adventif lebih dominan dan pada konsentrasi tinggi dapat merangsang pembentukan kalus (Pierik et al, 1987). Sitokinin berpengaruh terhadap pembelahan sel, proliferasi kalus, morfogenesis dengan menginisiasi akar, dan pembentukan tunas apikal maupun lateral dan berperan dalam perkembangan kloroplas (Wattimena, 1988).

Pembentukan kalus pada eksplan, secara fisiologi dipengaruhi oleh perubahan genetik pada sel tanaman oleh auksin. Sel yang merespon auksin akan menyebabkan dediferensiasi dan memacu pembelahan sel (George et al., 2008). Salah satu jenis auksin yang digunakan dalam kultur jaringan adalah Indole Acetic Acid (IAA). Senyawa IAA merupakan auksin alami pada tumbuhan yang disintesis dari triptofan di primordial daun, daun muda, dan biji yang sedang berkembang. IAA digunakan untuk mendorong pemanjangan sel serta menambah kemampuan sel dalam menyerap air, sehingga dapat meningkatkan potensial air jaringan akibatnya sel akan mengalami pemanjangan.

Penelitian mengenai induksi kalus sirih hitam pernah dilakukan, diantaranya Izdihar (2016) menyatakan bahwa induksi kalus yang optimal untuk eksplan daun Piper betle L. var Nigra adalah dengan kombinasi zat pengatur tumbuh IAA 1,0 $\mathrm{mg} / \mathrm{L}$ dan kinetin $1,5 \mathrm{mg} / \mathrm{L}$ kalus tumbuh pada hari ke 10 (lama waktu tercepat) 
dengan berat basah dan berat kering tertinggi. Zuraidassanaaz (2016) mengungkapkan bahwa pemberian kombinasi zat pengatur tumbuh IAA dan BAP $0,5 \mathrm{mg} / \mathrm{L}$ menghasilkan berat kering tertinggi sedangkan untuk berat basah tertinggi adalah dengan kombinasi zat pengatur tumbuh IAA $1,0 \mathrm{mg} / \mathrm{L}$ dan 1,5 $\mathrm{mg} / \mathrm{L}$. Hasil tercepat terbentuknya kalus adalah dengan lama waktu 8,5 hari dengan

\section{Metode Penelitian}

\section{Alat dan bahan}

Alat yang digunakan dalam penelitian ini adalah Laminar Air Flow (LAF), autoklaf, oven, timbangan analitik, botol kultur, cawan petri, gelas ukur, beaker glass, erlenmeyer, pipet, magnetic stirrer, aluminium foil, plastic wrap, kertas coklat, kertas $\mathrm{pH}$, pinset, scalpel, bunsen, gunting, kompor listrik, pengaduk, penyemprot alkohol (hand sprayer), cawan porselin, mortar.

Bahan yang digunakan dalam peneltian ini adalah daun kedua hingga keempat dari pucuk tanaman sirih hitam (Piper betle L.). Bahan-bahan kimia yang digunakan meliputi bahan penyusun media Murashige dan Skoog (MS), zat pengatur tumbuh Indole Acetic Acid (IAA), Benzyl Amino Purin (BAP), Kinetin, spiritus, larutan $\mathrm{HCI} 1 \mathrm{~N}$ dan $\mathrm{KOH} 1 \mathrm{~N}$, clorox $10 \%$, alkohol $70 \%$, akuades, metanol.

\section{Pembuatan media}

Pembuatan media Murashige dan Skoog (MS) dengan volume $1000 \mathrm{ml}$. unsur makronutrien yang telah ditimbang dilarutkan kedalam erlenmeyer $1000 \mathrm{ml}$ yang berisi $500 \mathrm{ml}$ akuades dan di homogenkan menggunakan magnetic stirrer. Setelah semua terlarut, ditambahkan stok mikronutrien, stok zat besi, stok vitamin, kemudian ditambahkan $100 \mathrm{~g}$ myo-inositol dan $30 \mathrm{~g}$ sukrosa. Zat pengatur tumbuh IAA ditambahkan pada media sesuai konsentrasi yang diinginkan. $\mathrm{pH}$ media diukur dengan kertas $\mathrm{pH}$ dengan pH optimal berkisar 5,6-5,8. Apabila kombinasi IAA $0,5 \mathrm{mg} / \mathrm{L}$ dan BAP 2,0 $\mathrm{mg} / \mathrm{L}$.

Mengacu pada penelitian-penelitian tersebut maka penelitian ini bertujuan untuk mengetahui jenis senyawa metabolit sekunder pada kalus sirih hitam (Piper betle L. var Nigra) dengan penambahan kombinasi konsentrasi zat pengatur tumbuh IAA, Kinetin dan BAP.

terlalu asam atau terlalu basa bisa di tambahkan $\mathrm{KOH}$ atau HCL, kemudian ditambahkan akuades hingga volume akhir $1000 \mathrm{ml}$. Dalam keadaan cair media di bagi dalam botol kultur masing masing sebanyak $20 \mathrm{ml} /$ botol. Botol kultur ditutup dengan aluminium foil dan diberi label sesuai perlakuan. Setelah media memadat, botol kultur di sterilisasi dalam autoklaf pada suhu $121^{\circ} \mathrm{C}$ dengan tekanan 1,2 atm selama 15 menit. Kemudian media yang sudah steril disimpan di ruang penyimpanan pada suhu kamar.

\section{Penamaan eksplan}

Proses penanaman eksplan dilakukan secara aseptis dalam laminar air flow (LAF). Sebelum LAF digunakan meja kerja yang ada didalamnya di bersihkan terlebih dahulu menggunakan kain lap bersih yang sudah disemprotkan alkohol $70 \%$. Seluruh alat dan bahan yang akan digunakan untuk menanam eksplan juga disemprot alkohol $70 \%$ dan dimasukkan ke dalam LAF. Alat dan bahan tersebut diantaranya botol kultur berisi media, pinset, skalpel, mata pisau, cawan petri, gelas ukur, erlenmeyer, daun sirih hitam yang sebelumnya telah dicuci dengan deterjen, clorox 10\%, akuades steril, plastic wrap, bunsen. Selanjutnya lampu ultra violet yang ada di dalam laminar air flow dinyalakan selama 15-20 menit. Setelah 20 menit lampu UV dimatikan dan lampu neon serta blower dinyalakan, maka ruang kerja siap digunakan. 
Sebelum ditanam eksplan di sterilisasi menggunakan clorox $10 \%$ dalam erlenmeyer dan digojok selama 7 menit, kemudian larutan clorox dibuang dan dibilas menggunakan akuades sebanyak 3 kali. Eksplan daun steril kemudian diambil dengan pinset dan dipotong dengan ukuran kurang lebih $1 \times 1 \mathrm{~cm}$ diatas cawan petri yang dialasi dengan kertas saring. Kemudian dimasukkan ke dalam botol kultur yang berisi media. Pinset dan skalpel harus selalu dipanaskan dengan api bunsen untuk memastikan tetap steril, sebelum di gunakan untuk mengambil atau memasukkan eksplan. Botol yang telah berisi eksplan ditutup menggunakan aluminium foil dan dilapisi dengan plastic wrap. Kemudian botol yang berisi eksplan tersebut diletakkan di dalam ruang inkubator dengan suhu $25^{\circ} \mathrm{C}$ dengan cahaya neon 20 watt secara terus menerus.

\section{Ekstraksi kalus sirih hitam}

Kalus yang terbentuk dari eksplan daun sirih hitam selama masa inkubasi dikeringkan dalam oven. Kalus kering tersebut dihaluskan dalam cawan porselin menggunakan mortar hingga menjadi serbuk. Serbuk diekstraksi dengan metode maserasi menggunakan pelarut metanol. Proses maserasi dilakukan dengan cara merendaman serbuk kalus dengan pelarut metanol selama 48 jam, kemudian dipisahkan ampas dan larutan dengan cara disaring menggunakan kertas saring.

\section{Hasil dan Pembahasan}

Hasil analisis senyawa dalam ekstrak metanol kalus sirih hitam pada perlakuan $\mathrm{I}_{1,0} \mathrm{~K}_{1,0}$ mengandung 26 jenis senyawa (Tabel 1). Dari semua jenis senyawa tersebut, 5 jenis senyawa dengan presentase luas area terbesar adalah Hexadecanoic acid (20,69\%); Oleic Acid (15,2\%); Gamma sitosterol (14,88\%); dan Linoelaidic Acid (12,73\%); Beta - $\mathrm{H}$ Pregna (7,44\%). Gamma sitosterol dan Beta-H-Pregna merupakan senyawa metabolit sekunder golongan steroid, sedangkan Hexadecanoic acid, Oleic Acid,
Larutan tersebut kemudian dikering anginkan, sehingga terbentuklah ekstrak kalus sirih hitam.

\section{Analisis Gas Chromatography-Mass Spectrometry (GC-MS)}

Ekstrak kalus sirih hitam di analisis dengan GCMS-Agilent 19091S-105. Gas helium digunakan sebagai gas pembawa dengan kecepatan $1 \mathrm{ml} / \mathrm{min}$, ukuran sampel $1 \mu \mathrm{L}$ yang diinjeksikan menggunakan kapiler silika kolom HP-5 $(60 \mathrm{~m} \times 200 \mu \mathrm{m} \times 0,33 \mu \mathrm{m})$. Suhu oven $40^{\circ} \mathrm{C}$ selama 5 menit, kemudian dinaikkan hingga mencapai $250^{\circ} \mathrm{C}$ dengan laju $2^{\circ} \mathrm{C} /$ menit. Total running time $\mathrm{GC}$ adalah 130 menit. Spektrum massa dari senyawa tersebut dibandingkan dengan standar yang ada pada data base Library Willey. Library Willey merupakan perpustakaan senyawa-senyawa yang digunakan sebagai standar untuk mencocokkan senyawa yang teridentifikasi pada sampel.

Hasil maserasi pada masing-masing perlakuan kalus, selanjutnya dilakukan identifikasi senyawa-senyawa metabolit sekunder dengan menggunakan GC-MS. Hasil maserasi yang berupa ekstrak diinjeksikan pada alat Gas Chromatography Mass Spectrometry (GCMS). Setelah itu akan didapatkan profil keseluruhan senyawa yang terekam pada komputer. Data pada komputer menunjukkan jumlah dan jenis senyawa ekstrak kalus sirih hitam.

dan Linoelaidic Acid merupakan senyawa metabolit primer golongan asam lemak. Senyawa Linoelaidic acid atau dapat disebut juga asam linoleat merupakan rantai panjang lemak tak jenuh ganda yang mengandung omega 6 (Diana, 2012). Asam linoleat memiliki aktivitas anti histaminic, anti coronary, anti acne, anti bakteri, anti jamur, anti arthritis, dan anti inflamasi (Dineskumar, 2015). Menurut $\mathrm{Wu}$ et al. (2010) asam linoleat juga memiliki aktivitas seperti hepatoprotective dan hypocholestrolemic. Asam linoleat 
juga dapat ditemukan dalam analisis dengan luas area sebesar 12,96 \% GCMS terhadap ekstrak etanol (Gopalakrishnan, 2014). Pada extract Pleiospermium alatum, dengan luas area metanol kalus Justicia gendarussa sebesar 8,36\% (Parthipan, 2015), juga kombinasi IAA dan BAP, teridentifikasi dalam ekstrak Fluggea leucopyrus dengan secara GCMS dengan luas area sebesar luas area 5,78 \% (Sudha, 2013), serta 0,88\% (Wahyuni, et al 2017). dalam ekstrak daun Marsilea quadrifolia

Tabel 1. Hasil identifikasi kandungan senyawa ekstrak metanol kalus sirih hitam perlakuan

\begin{tabular}{|c|c|c|c|}
\hline No & $\begin{array}{c}\text { Waktu Retensi } \\
\text { (menit) }\end{array}$ & $\begin{array}{c}\text { Luas area } \\
(\%)\end{array}$ & Nama Senyawa \\
\hline 1 & 8,840 & 0,42 & Pyridine \\
\hline 2 & 11,621 & 0,52 & Pyrazine \\
\hline 3 & 12,125 & 0,31 & 2-Furancarboxaldehyde \\
\hline 4 & 19,483 & 0,93 & 5-Methyl furfural \\
\hline 5 & 36,895 & 0,80 & 1-Pyrrolidineethanamine \\
\hline 6 & 37,124 & 0,95 & Cyclopentamine \\
\hline 7 & 49,953 & 3,38 & L-Proline, 5-oxo-, Methyl ester \\
\hline 8 & 68,034 & 0,49 & Benzyl methyl ether \\
\hline 9 & 71,690 & 0,52 & Tetradecanoid acid \\
\hline 10 & 71,845 & 0,01 & Beta D-Glucopyranoside \\
\hline 11 & 81,941 & 20,69 & Hexadecanoic acid \\
\hline 12 & 86,035 & 0,17 & 1-Octadecene \\
\hline 13 & 87,014 & 5,71 & 1-Octadecanol \\
\hline 14 & 88,324 & 1,26 & Benzyl methyl ether \\
\hline 15 & 89,629 & 12,73 & Linoelaidic acid \\
\hline 16 & 89,921 & 15,26 & Oleic Acid \\
\hline 17 & 95,809 & 1,52 & Cyclohexadecane \\
\hline 18 & 100,119 & 7,44 & Beta -H-Pregna \\
\hline 19 & 100,598 & 0,11 & Octatriacontyl pentafluoropropionate \\
\hline 20 & 100,621 & 0,13 & Cyclooctacosane \\
\hline 21 & 103,573 & 0,26 & Dotriacontyl heptafluorobutyrate \\
\hline 22 & 110,211 & 0,26 & Hentriacontane \\
\hline 23 & 113,043 & 0,97 & Tetratriacontyl pentafluoropropion \\
\hline 24 & 117,483 & 1,53 & Squalene \\
\hline 25 & 119,738 & 0,10 & 1-Bromo-11-iodoundecane \\
\hline 26 & 127,800 & 14,88 & Gamma sitosterol \\
\hline
\end{tabular}


Pada Tabel 2 pada perlakuan $\mathrm{I}_{1,0} \mathrm{~K}_{1,5}$ menunjukkan bahwa terdapat 32 jenis senyawa fitokimia yang diprediksi terkandung dalam ekstrak kalus dengan perlakuan $\mathrm{I}_{1,0} \mathrm{~K}_{1,5}$ dalam retensi waktu 1 hingga 122 menit. Masing-masing senyawa memiliki luas area yang berbeda-beda. Lima senyawa dengan presentase luas area tertinggi di antaranya 14-BetaH-Pregna (15,94 \%); Oleic acid (10,86\%); L-proline, 5-oxo, methyl ester (7,86\%); Hexadecanoic acid (7,25\%); dan Dotriacontyl heptafluorobutyrate (3,77\%).

Tabel 2. Hasil identifikasi kandungan senyawa ekstrak metanol kalus sirih hitam perlakuan

\begin{tabular}{|c|c|c|c|}
\hline No & $\begin{array}{c}\text { Waktu Retensi } \\
\text { (menit) }\end{array}$ & $\begin{array}{c}\text { Luas area } \\
(\%)\end{array}$ & Nama Senyawa \\
\hline 1 & 6,815 & 0,26 & Butanal \\
\hline 2 & 7,307 & 0,41 & Silane, dimethoxymethyl \\
\hline 3 & 8,840 & 0,23 & Pyridine \\
\hline 4 & 11,564 & 0,13 & Pyrazine \\
\hline 5 & 12,050 & 0,10 & 2-furancarboxaldehyde \\
\hline 6 & 16,290 & 0,14 & Oxirane, 2-ethyl-2-methyl \\
\hline 7 & 19,357 & 0,44 & Methyl furfural \\
\hline 8 & 27,711 & 0,25 & 2-Pyrrolidinone \\
\hline 9 & 29,222 & 0,26 & Oxcalic acid \\
\hline 10 & 35,470 & 0,52 & Formyl glutamine \\
\hline 11 & 48,368 & 1,03 & 2-piperidinecarboxcylic acid \\
\hline 12 & 48,717 & 0,97 & 4-methylproline methyl ester \\
\hline 13 & 50,176 & 7,86 & L-proline, 5-oxo, methyl ester \\
\hline 14 & 51,973 & 0,68 & Piperidinemethanol \\
\hline 15 & 78,831 & 0,11 & 1-Glutamic acid \\
\hline 16 & 81,898 & 7,25 & Hexadecanoic acid \\
\hline 17 & 86,997 & 3,72 & 1- Octadecane \\
\hline 18 & 89,617 & 4,19 & Linoelaidic acid \\
\hline 19 & 89,892 & 10,86 & Oleic acid \\
\hline 20 & 90,819 & 1,27 & Octadecanoic acid \\
\hline 21 & 100,152 & 0,08 & Cyclohexadecane \\
\hline 22 & 105,433 & 0,94 & Celidoniol deoxy \\
\hline 23 & 106,537 & 0,90 & 9-Eicosene \\
\hline 24 & 107,098 & 1,07 & Octatriacontyl pentafluoropropionate \\
\hline 25 & 108,591 & 15,94 & 14-Beta-H-Pregna \\
\hline 26 & 110,176 & 1,94 & Propionic acid, 3-iodo, octadecylester \\
\hline 27 & 110,325 & 1,31 & Aspidospermidin \\
\hline 28 & 111,304 & 1,52 & 1-octadecanol \\
\hline 29 & 113,192 & 3,77 & Dotriacontyl heptafluorobutyrate \\
\hline 30 & 114,050 & 0,59 & Hexatriacontyl pentafluoropropiona \\
\hline 31 & 117,466 & 3,75 & Squalene \\
\hline 32 & 122,627 & 3,09 & Silane, trichlorooctadecyl \\
\hline
\end{tabular}


Pada Tabel 3 pada perlakuan $\mathrm{I}_{1,0} \mathrm{~B}_{1,5}$ menunjukkan bahwa terdapat 26 jenis senyawa fitokimia yang di prediksi terkandung dalam ekstrak kalus dengan perlakuan $\mathrm{I}_{1,0} \mathrm{~B}_{1,5}$ dalam retensi waktu 1 hingga 127 menit. Masing-masing senyawa memiliki luas area yang berbeda- beda. Lima senyawa dengan presentase luas area tertinggi di antaranya Hexadecanoid acid (18,75\%); Linoelaidic acid (17,07\%); Oleic acid (16,13\%); Beta, D-Glucopyranoside, methyl $(15,54 \%)$; dan Heptanoic acid $(3,05 \%)$.

Tabel 3. Hasil identifikasi kandungan senyawa ekstrak metanol kalus sirih hitam perlakuan

\begin{tabular}{|c|c|c|c|}
\hline No & $\begin{array}{c}\mathrm{l}_{1,0} \mathrm{~B}_{1,5} \\
\text { Waktu Retensi } \\
\text { (menit) }\end{array}$ & $\begin{array}{c}\text { Luas area } \\
(\%)\end{array}$ & Nama Senyawa \\
\hline 1 & 6,678 & 0,39 & Butanal \\
\hline 2 & 8,823 & 0,42 & Pyridine \\
\hline 3 & 11,558 & 0,56 & 2-methyl pyrazine \\
\hline 4 & 12,045 & 0,89 & 2-furan-carboxadehyde \\
\hline 5 & 14,671 & 0,24 & Protoanemonine \\
\hline 6 & 16,394 & 0,15 & Piperazine \\
\hline 7 & 19,352 & 1,17 & 5-methyl furfural \\
\hline 8 & 37,290 & 1,53 & Glutamine \\
\hline 9 & 50,382 & 1,77 & Methyl 5-oxo-2-pyrrolidinecarboxylate \\
\hline 10 & 71,776 & 1,26 & Tetradecanoic acid \\
\hline 11 & 73,527 & 15,54 & Beta, D-Glucopyranoside, methyl \\
\hline 12 & 74,540 & 3,05 & Heptanoic acid \\
\hline 13 & 79,638 & 0,84 & Hexadecanoic acid, methyl ester \\
\hline 14 & 82,110 & 18,75 & Hexadecanoid acid \\
\hline 15 & 86,276 & 0,55 & Trans-2-tridecenal \\
\hline 16 & 86,985 & 0,97 & 1-Octadecene \\
\hline 17 & 89,881 & 17,07 & Linoelaidic acid \\
\hline 18 & 90,144 & 16,13 & Oleic acid \\
\hline 19 & 95,797 & 0,32 & 5-Eicosene \\
\hline 20 & 106,063 & 0,35 & Acetic acid \\
\hline 21 & 107,813 & 0,33 & 2,6,10-dodecatrienal, 3,7,11 trimethyl \\
\hline 22 & 109,490 & 0,60 & Glycine \\
\hline 23 & 110,171 & 0,28 & 1-Octadecanol \\
\hline 24 & 113,020 & 0,64 & 14 beta H- Pregna \\
\hline 25 & 117,461 & 1,07 & Squalene \\
\hline 26 & 127,028 & 2,21 & gamma sitosterol \\
\hline
\end{tabular}


Pada Tabel 4 pada perlakuan $\mathrm{I}_{05} \mathrm{~B}_{0,5}$ menunjukkan bahwa terdapat 25 jenis senyawa fitokimia yang di prediksi terkandung dalam ekstrak kalus dengan perlakuan $\mathrm{I}_{05} \mathrm{~B}_{0,5}$ dalam retensi waktu 1 hingga 127 menit. Masing-masing senyawa memiliki luas area yang berbeda- beda. Lima senyawa dengan presentase luas area tertinggi diantaranya Linoelaidic acid (28,52\%); Hexadecanoic acid (22,30\%); Beta.-D-Glucopyranoside, methyl (5,63\%); Gamma - sitosterol $(4,30 \%)$ dan Octadecanoic acid (3,95\%).

Tabel 4. Hasil identifikasi kandungan senyawa ekstrak metanol kalus sirih hitam pada perlakuan $\mathrm{I}_{05} \mathrm{~B}_{0,5}$

\begin{tabular}{cccc}
\hline No & $\begin{array}{c}\text { Waktu Retensi } \\
\text { (menit) }\end{array}$ & $\begin{array}{c}\text { Luas area } \\
(\boldsymbol{\%})\end{array}$ & Nama Senyawa \\
\hline 1 & 8,783 & 0,42 & Pyridine \\
2 & 11,507 & 0,85 & Pyrazine metyl \\
3 & 11,982 & 0,62 & Furfural \\
4 & 14,637 & 0,40 & Protoanemonine \\
5 & 19,266 & 0,84 & 5-Methyl furfural \\
6 & 24,622 & 0,18 & Benzeneacetaldehyde \\
7 & 29,411 & 0,62 & 2-Pyrrolidinone \\
8 & 37,279 & 0,47 & L-Glutamine \\
9 & 47,504 & 0,37 & 2-methoxy-3-methylhydroquinon \\
10 & 50,657 & 1,81 & DL-Proline, 5-oxo-methhyl ester \\
11 & 71,805 & 0,42 & Tetradecanoic acid \\
12 & 75,301 & 5,63 & Beta.-D-Glucopyranoside, methyl \\
13 & 76,022 & 0,83 & Heptanoic Acid \\
14 & 80,714 & 2,01 & Pentadecanoic acid \\
15 & 82,190 & 22,30 & Hexadecanoic acid \\
16 & 87,008 & 2,83 & 1-Octadecanol \\
17 & 90,201 & 28,52 & Linoelaidic acid \\
18 & 91,037 & 3,95 & Octadecanoic acid \\
19 & 95,809 & 0,53 & 1-Hexadecane \\
20 & 106,068 & 0,35 & Acetic acid \\
21 & 110,188 & 0,56 & Linoleic acid ethyl ester \\
22 & 114,783 & 0,22 & 7-Pentadecyne \\
23 & 115,035 & 1,30 & 14-beta-H- Pregna \\
24 & 117,461 & 1,64 & Squalene \\
25 & 127,222 & 4,30 & Gamma sitosterol \\
\hline
\end{tabular}

Senyawa Hexadecanoic acid atau dapat disebut juga asam palmitat memiliki efek anti bakteri dan kolestrolemik (Dineshkumar, 2015). Menurut Jegadeeswari et al (2012) Senyawa hexadecanoic acid atau asam palmitat memiliki aktifitas sebagai antioksidan, anti androgenik, anti fungal, anti tumor, anti bacterial, hemolytic, pesticide, dan lubricant. Pada extract metanol kalus Justicia gendarussa perlakuan kombinasi IAA dan BAP, teridentifikasi secara
GCMS dengan luas area sebesar 2,69\% (Wahyuni, et al 2017). Senyawa Hexadecanoic acid juga dapat ditemukan dalam analisis GCMS terhadap ekstrak etanol Pleiospermium alatum, dengan luas area sebesar 6,11\% (Parthipan, 2015), juga dalam ekstrak daun Marsilea quadrifolia dengan luas area sebesar 17,47\% (Gopalakrishnan, 2014). Hexadecanoic acid sebesar 1,61\% juga teridentifikasi dengan GCMS pada ekstrak kalus Solanum melongena (Vanitha, 2016). 
Senyawa gamma sitosterol selain pada perlakuan $\mathrm{I}_{1,0} \mathrm{~K}_{1,0}$ juga teridentifikasi pada perlakuan $\mathrm{I}_{05} \mathrm{~B}_{0,5}$ dengan luas area $4,30 \%$ dan I1,0 B1,5 dengan luas area 2,21\%, luas area terbesar yaitu $14,88 \%$ terdapat pada perlakuan $\mathrm{I}_{1,0} \mathrm{~K}_{1,5}$. Senyawa gamma sitosterol berperan dalam mengurangi hiperglikemia dan penghambatan glikogenesis, sehingga dapat digunakan dalam pengobatan diabetes melitus, senyawa gamma sitosterol juga ditemukan pada analisis GCMS terhadap ekstrak daun Girardinia heterophylla (Tripathi, 2013). Menurut Balamurugan (2011), gamma sitosterol dapat dipertimbangkan untuk menjadi obat anti diabetic. Dalam penelitian Anand, et al (2018) dalam ekstrak metanol kalus Ampelicissus latifolia teridentifikasi secara GCMS senyawa gamma sitosterol dengan luas area sebesar 9,19\%, senyawa ini memiliki aktivitas anti microbial, anti inflamatory, anti kanker, dan anti oksidan.

Selanjutnya senyawa 14 Beta H Pregna juga ditemukan pada semua perlakuan $\left(\mathrm{I}_{1,0} \mathrm{~K}_{1,5} ; \quad \mathrm{I}_{1,0} \mathrm{~B}_{1,5} ; \quad \mathrm{I}_{05} \mathrm{~B}_{0,5} \quad\right)$. Perlakuan dengan luas area terbesar adalah $\mathrm{I}_{1,0} \mathrm{~K}_{1,5}$ dengan luas area 15,94\% dan luas area terendah sebesar $0,64 \%$ pada perlakuan $\mathrm{I}_{1,0} \mathrm{~B}_{1,5}$. Senyawa 14 Beta $H$ Pregna memiliki sifat anti diabetik, seperti halnya dalam penelitian ini senyawa 14 Beta $H$ Pregna juga ditemukan dalam Urginea indica sebesar 0,50 \% (Prabakaran, 2016).

Hasil analisis senyawa dari ekstrak metanol kalus sirih hitam pada perlakuan $\mathrm{I}_{1,0} \mathrm{~K}_{1,5}$ mengandung 32 jenis senyawa. Dari semua jenis senyawa tersebut, 5 jenis senyawa dengan presentase luas area terbesar adalah Senyawa 14 Beta $H$ Pregna dengan waktu retensi 108,59 menit, luas area $15,94 \%$. Oleic acid dengan waktu retensi 89,89 menit, luas area 10,86 \%. L-proline-5-oxo-methyl ester dengan waktu retensi 50,17 menit, luas area 7,86 \%. Hexadecanoic acid dengan waktu retensi 81,89 menit, luas area $7,25 \%$. Linoelaidic acid dengan waktu retensi 89,1 menit, luas area 4,19\%. L-proline-5-oxo-methyl ester merupakan senyawa metabolit sekunder golongan alkaloid. Selain teridentifikasi pada perlakuan $\mathrm{I}_{1,0} \mathrm{~K}_{1,5}$ L-proline-5-oxo-methyl ester juga dapat ditemukan pada semua perlakuan $\left(\mathrm{I}_{1,0} \mathrm{~K}_{1,5} ; \mathrm{I}_{1,0} \mathrm{~B}_{1,5} ; \mathrm{I}_{05} \mathrm{~B}_{0,5}\right)$. Luas area terbesar terdapat pada perlakuan $\mathrm{I}_{1,0} \mathrm{~K}_{1,5}$ sebesar $7,8 \%$, sedangkan luas area terendah terdapat pada perlakuan $\mathrm{I}_{1,0} \mathrm{~B}_{1,5}$ sebesar $1,77 \%$.

Senyawa oleic acid selain pada perlakuan $\mathrm{I}_{1,0} \mathrm{~K}_{1,5}$ dengan luas area $10,8 \%$ juga terdapat dalam perlakuan $\mathrm{I}_{1,0} \mathrm{~B}_{1,5}$ dengan luas area terbesar yaitu $16,13 \%$. Senyawa oleic acid atau dapat disebut juga asam oleat merupakan rantai panjang asam lemak tak jenuh tunggal yang mengandung omega 9 memiliki aktivitas anti tumor dan anti inflammatory, menurut Romero (2007) asam oleat memiliki memiliki aktifitas bakterisidal terhadap Helicobacter pylori, yang merupakan agen penyebab ulkus lambung. Konsumsi asam oleat yang tinggi dapat mengurangi resiko perkembangan kanker, terutama kanker payudara dan prostat (Campos, 2013). Menurut Teres (2008), asam oleat dapat menghambat perkembangan adrenoleukodystrophy (ALD) penyakit fatal yang mempengaruhi otak dan kelenjar adrenal. Asam oleat juga bertanggung jawab untuk mengurangi tekanan darah. Dalam penelitian Parthipan et al (2015) asam oleat ditemukan dalam analisis GCMS terhadap ekstrak etanol Pleiospermium alatum, dengan luas area sebesar 5,88\%.

Hasil analisis senyawa dari ekstrak metanol kalus sirih hitam pada perlakuan $\mathrm{I}_{1,0} \mathrm{~B}_{1,5}$ mengandung 26 jenis senyawa (Tabel 4.8). Dari semua jenis senyawa tersebut, 5 jenis senyawa dengan presentase luas area terbesar adalah Hexadecanoic acid dengan waktu retensi 82,11 menit, luas area 18,75 \%. Linoelaidic acid dengan waktu retensi 89,88 menit, luas area $17,07 \%$. Oleic acid dengan waktu retensi 90,14 menit, luas area 16,13 \%. Beta D-glucopyranoside methyl dengan waktu retensi 73.52 menit, luas area 15,54\%. Heptanoic acid dengan 
waktu retensi 74,54 menit, luas area 3,05 $\%$. Beta D-glucopyranoside methyl merupakan senyawa metabolit sekunder golongan flavonoid, selain teridentifikasi dalam perlakuan $I_{1,0} B_{1,5}$ dengan luas area terbesar yaitu $15,54 \%$, Beta Dglucopyranoside methyl juga terdapat dalam perlakuan $\mathrm{I}_{1,0} \mathrm{~B}_{1,5}$ dengan luas area $5,63 \%$.

Senyawa Heptanoic acid juga teridentifikasi pada perlakuan $\mathrm{I}_{05} \mathrm{~B}_{0,5}$ dengan luas area $0,83 \%$. Luas area terbesar yaitu 3,05\% terdapat pada perlakuan $\mathrm{I}_{1,0} \mathrm{~B}_{1,5}$. Senyawa Heptanoic acid tidak ditemukan dalam perlakuan IAA-Kinetin, hal ini sejalan dengan penelitan Wahyuni menggunakan ekstrak metanol daun Justicia gendarussa dengan analisis GCMS teridentifikasi senyawa Heptanoic acid pada ekstrak metanol kalus Justicia gendarussa sebesar 1,68\% pada perlakuan NAA-Kinetin, namun tidak teridentifikasi pada perlakuan IAAKinetin. Heptanoic acid memiliki aktivitas anti inflamasi.

Dalam penelitian Kala (2018) ekstrak metanol kalus daun Biophytum sensitivum teridentifikasi senyawa octadecanic acid sebesar 5,25\%. Octadecanic acid terdiri dari antihipertensi, meningkatkan HDL dan menurunkan Kolesterol LDL. Asam Oktadekanoat adalah asam lemak jenuh, dan menunjukkan penurunan tingkat Kolesterol LDL yang lebih Rendah. Asam lemak tak jenuh penting untuk pertumbuhan normal, terutama pembuluh darah dan saraf untuk menjaga kulit dan jaringan lain agar tetap muda dan sehat. Di sisi lain asam oktadekanoat memiliki aktivitas antibakteri dan anti fungal (Gopalakrishna, 2014). Dalam penelitian
Wahyuni (2017) menggunakan ekstrak metanol daun Justicia gendarussa dengan analisis GCMS teridentifikasi senyawa octadecanoic acid sebesar 6,41 \%, luas area tersebut terdapat pada kombinasi perlakuan IAA dan BAP. Sedangkan dalam penelitian ini ditemukan senyawa octadecanoic acid dengan luas area lebih kecil yaitu, sebesar 3,95 \%. Senyawa octadecanoic acid juga mengandung anti oksidan (Wahyuni, 2016). Senyawa gamma sitosterol, 14-beta-h-pregna, betad-glucopyranoside, dan L-proline-5-oxomethyl ester merupakan senyawa baru yang di temukan pada ekstrak kalus sirih hitam kombinasi IAA, BAP, kinetin, dan senyawa tersebut tidak ditemukan pada ekstrak daun sirih hitam (Junairiah, et al 2018).

\section{Kesimpulan}

Senyawa metabolit sekunder dengan jumlah tertinggi pada ekstrak metanol perlakuan $\mathrm{I} 1,0 \mathrm{~K} 1,0$ adalah senyawa gamma sitosterol $(14,88 \%)$; ekstrak metanol pada perlakuan $\mathrm{I} 1 \mathrm{~K} 1,5$ adalah senyawa 14 -betah-pregna $(15,94 \%)$; ekstrak metanol pada perlakuan $\mathrm{I} 0,5 \mathrm{~B} 0,5$ adalah senyawa beta-dglucopyranoside (15,54\%); dan ekstrak metanol pada perlakuan I1,0 B1,5 adalah senyawa beta-d-glucopyranoside $(5,63 \%)$.

\section{Ucapan Terima Kasih}

Penulis mengucapkan terima kasih kepada Kementerian Riset, Teknologi dan Pendidikan Tinggi yang memberikan dana penelitian melalui hibah penelitian PTUPT (Penelitian Terapan Unggulan Perguruan Tinggi). 


\section{Daftar Pustaka}

Agusta, A. 2000. Minyak Atsiri Tumbuhan Tropika Indonesia. Bandung: ITB Press.

Anand, D. C., Meena, R., \& Patni, V. 2018. In Vitro Callus Induction and Comparative GC-MS Analysis of Methanolic Extract of Callus and Leaf Samples of Ampelocissus latifolia (Roxb) Planch. International Journal of Pharmacy and Pharmaceutical Science, 10(9), 68-72.

Balamurugan, R., Duraipandiyan, V., \& Ignacimuthu, S. 2011. Antidiabetic Activity of $\gamma$-Sitosterol Isolated from Lippia nodiflora L. in Streptozotocin Induced Diabetic Rats. European Journal Pharmacology, 667, 410-418.

Campos, H. E., Peghini, B. C., Souza, P. R., \& Silva, J. S. 2012. An Overview of the Modulatory Effect of Oleic Acid in Health and Disease. MiniReviews in Mdicinal Chemistry, 13(2), 1-7.

Dineshkumar, G. And Rajakumar, R. 2015. GC-MS Evaluation of Bioactive Molecules from the Methanolic Leaf Extract of Azadirachta indica. Asian Journal of Pharmaceutical Science \& Technology, 5(2), 64-69.

Diana, F, M. 2012. Omega 6. Jurnal Kesehatan Masyarakat, 7(1), 26-31.

George, E. F \& P. D. Sherington. 1984. Plant Propagation by Tissue Culture. England: Handbook and Directory of Comercial Laboratories, Easter Press.

Gopalakrishna, N. K., \& Udayakumar, R. 2014. GC-MS Analysis of Phytocompounds of Leaf and Stem of Marsilea quadrifolia (L.). International Journal of Biochemistry Research \& Review, 4(6), 517-526.

Hariana, A. 2007. Tumbuhan Obat dan Khasiatnya. Jakarta: Penebar Swadaya.

Hutapea, Johnny, Ria, dkk. 2000. Inventaris Tanaman Obat Indonesia III. Jakarta: Badan Penelitian dan Pengembangan Kesehatan.
Jegadeeswari, P., Nishanthini, A., Muthukumaraswamy, S., Mohan, V. R. 2012. GC-MS Analysis of Bioactive Components of Aristolochia krysagathra (Aristolochiaceae). Journal Chemical Pharmaceutical Science, 2, 226-236.

Junairiah, Ni'matuzahroh, \& Sulistyorini, L. 2018. GCMS Analysis of Bioactive Compounds in n-Hexane, Ethyl Acetate, and Methanol Extract of Piper betle L. var. Nigra. Bioscience Research, 15(3), 1472-1479.

Kartsapoetra, G. 1992. Budidaya Tanaman Berkhasiat Obat. Jakarta: Rineka Cipta.

Mahendra, B. 2005. Jenis Tanaman Obat Ampuh. Jakarta: Penebar Swadaya.

Parthipan, B., Suky, M. G. T., \& V. R. Mohan. 2015. GC-MS Analysis of Phytocomponents in Pleiospermium alatum (Wall. ex Wight \& Arn.) Swingle, (Rutaceae). Journal of Farmcognosy and Phytochemistry, 4(1), 216-222.

Prabakaran, R., Joseph, B., \& Pradeep P. N. 2016. Phyto Medicinal Compounds from Urginea indica Kunth: A Synthetic Drugs Potential Alternative. British Journal of Pharmaceutical Research, 11(5), 1-9.

Pierik, R. I. M. 1987. In Vitro Culture of Higher Plants: 119. Netherlands: Martinus Nijhoff Publishers.

Romero, C., Medina, E., Vargas, J., Brenes, M., \& De Castro, A. 2007. In Vitro Activity of Olive Oil Polyphenols Against Helicobacter pylori. Journal Agricultural Food Chemical, 55, 680-686

Sudha, T., Chidambarampillai, S., \& Mohan, V. R. 2013. GC-MS Analysis of Bioactive Components of Aerial Parts of Fluggea leucopyrus Willd. (Euphorbiaceae). Journal of Applied Pharmaceutical Science, 3(5), 126130. 
Sutriana, S., Jumin, H. B., \& Gultom, H. 2012. Interaksi BAP (Benzil Amino Purin) dan IAA (Indole Acetic Acid) pada Eksplan Anthurium sp. dalam Kultur Jaringan. Dinamika Pertanian, XXVII (3), 131-140.

Teres, S., Barcelo-Coblijn, G., Benet, M., Alvarez, R., Bressani, R., \& Halver, J. E. 2008. Oleic Acid Content is Responsible for the Reduction in Blood Pressure Induced by Olive Oil. Pro. Natl Acad Sci USA, 105, 1381113816.

Tripathi, N., Kumar, S., Rakesh S., Singh, C.J., Prashant, S., \& V.K.Varshne. 2013. Isolation and Identification of $\gamma$ Sitosterol by GC-MS from the Leaves of Girardinia heterophylla. The Open Bioactive Compounds Journal, 4, 2527.

Vanitha, A., Kalimuthu, K., Chinnadurai, V., Sharmila Juliet., Y., \& Prabakaran R. 2016. GCMS Analysis of Leaf and
Salt Stress Callus of Eggplant (Solanum melongena L). British Journal of Pharmaceutical Research, 14(6), 1-11.

Wahyuni, D. K, Ansori, A. N. M., Vidiyanti, F. 2017. GC-MS Analysis of Phytocomponents in Methanolic Extract of Leaf-Derived Callus of Justicia gendarussa Burm.f. Bioscience Research, 14(3), 668-677.

Wattimena, Gunawan, L.W., \& Armini A. N. 1992. Bioteknologi Tanaman. Bogor: Laboratorium Kultur Jaringan Tanaman, Pusat Antar Spesies IPB.

Wu, L., Gao, H., Wang, X., Ye, J., Lu, J., \& Liang, Y. 2010. Analysis of Chemical Composition of Chrysanthemum indicum Flowers by GC/MS and HPLC. Journal Medicinal Plants Research, 4(5), 421426.

Zulkarnain. 2011. Kultur Jaringan Tanaman. Jakarta: Bumi Aksara. 